\title{
Serum Immunoglobulins (IgG, IgM and IgA) in Nigerian Women with Breast Cancer
}

\author{
Chukwurah Ejike Felix ${ }^{1 *}$, Ogbodo Sylvester Ogbonna², Chukwurah Felix Chinedum ${ }^{3,4}$ \\ ${ }^{1}$ Department of Haematology \& Immunology, Faculty of Medicine, Ebonyi State University, Abakaliki, Nigeria \\ ${ }^{2}$ Department of Medical Biochemistry, College of Medicine, Enugu State University of Science \& Technology, Enugu, Nigeria \\ ${ }^{3}$ Shenyang Medical College, Shenyang, China \\ ${ }^{4}$ Department of Surgery, Enugu State University Teaching Hospital, Enugu, Nigeria \\ Email: ^medichemlabenugu@yahoo.com, osylver1@yahoo.com,dr_felix@outlook.com
}

How to cite this paper: Felix, C.E., Ogbonna, O.S. and Chinedum, C.F. (2018) Serum Immunoglobulins (IgG, IgM and IgA) in Nigerian Women with Breast Cancer. Open Journal of Immunology, 8, 81-95. https://doi.org/10.4236/oji.2018.83005

Received: July 9, 2018

Accepted: September 4, 2018

Published: September 7, 2018

Copyright $\odot 2018$ by authors and Scientific Research Publishing Inc. This work is licensed under the Creative Commons Attribution International License (CC BY 4.0).

http://creativecommons.org/licenses/by/4.0/

(c) (i) Open Access

\begin{abstract}
Background: Breast cancer remains intractable and the leading cause of cancer related death among women. The appearance of breast tumour and its progression poses great clinical unpredictability before and after diagnosis, therapy and appearance of recurrent secondary deposits. Various immunological changes occur during breast tumourigenesis, and can be of value in the surveillance of the diseases. In our environment, there is scanty information on the value of these immunological factors especially immunoglobulins in screening and surveillance of breast cancer-hence the need for this study. Methodology: A total of 59 females (mean age $=48.7 \pm 8.7 \mathrm{yrs}$ ) with clinically and pathologically confirmed breast cancer were prospectively recruited alongside with 20 patients with benign breast tumour representing patients' control group and 20 apparently healthy age and sex-matched control subjects (mean age $=47.5 \pm 13.4 \mathrm{yrs}$ ). Breast cancer patients were further grouped into early stage breast cancer $(\mathrm{N}=25)$ and advanced stage breast cancer $(\mathrm{N}=34)$. Patients were subjected to standard treatment modalities and pre- and post-treatment samples collected at intervals. Samples were assayed for IgG \& IgM by immunoenzymatic methods and IgA by immunoturbidimetric method. Questionnaires and measurements were used to obtain necessary demographic and anthropologic information from the subjects. Results: Results showed that in all stages of breast cancer and treatment groups, the mean serum IgG, IgM and IgA levels respectively were not significantly raised $(\mathrm{P}>0.05)$ when compared. Results also showed that majority $(59 \%)$ of the patients presented at advanced stage of the disease. Low level of education and low income were among the prevailing risk factors. Majority $(63 \%)$ of the cases had body mass index suggesting obesity $\left(>30 \mathrm{~kg} / \mathrm{m}^{2}\right)$. Conclusion: Results suggest that serum immunoglobulin (IgG, IgM and IgA) levels are
\end{abstract}


of limited value in surveillance of breast cancer in our environment. Based on our findings, it could also be concluded that low levels of education and low income are among the risk factors. Advocacy and evidence based policies aimed at prevention and early detection of the disease should be prioritized.

\section{Keywords}

Breast Tumour, Immunoglobulins, Treatment and Disease Surveillance

\section{Introduction}

Breast cancer remains intractable and the leading cause of cancer related death among women worldwide. The prevalence is increasing even in African countries that used to have low but present with more aggressive, increased mortality, earlier age at presentation (35 - 45 years) and different patterns of gene expression [1] [2] [3]. Most of the studies in Nigeria confirm late presentation with advanced disease and poor clinical outcome [4] [5] [6] [7]. Early detection therefore is of immense clinical importance.

The appearance of breast tumour and its progression poses great clinical unpredictability before and after diagnosis, therapy and appearance of recurrent secondary deposits. Biological markers are widely recognized as important tools in the evaluation and management of patients with cancer and an especially wide array of body fluid markers have been investigated for clinical utility in diagnosing, staging or managing patients with cancer [8]-[17].

The earlier classic understanding that immunoglobulins were produced only by B lymphocytes and plasma cells were challenged when many non-lymphoid lineage cells (such as breast cancer cells) were found to have the ability to produce IgG [18] [19]. Previously, possible disturbance in the secretory immune system leading to defect in immunoglobulin metabolism has been suggested in pathogenesis of breast cancer [20]. Serum immunoglobulins levels were found to be related to disease stage and tumour burden in cancers such as carcinoma of cervix [21], pancreatic cancer [22], primary liver carcinoma [23] and squamous cell carcinoma [24]. In oral cancer patients, previous investigations of serum immunogloblin levels showed an increase in IgM, IgA, IgE, and IgG when compared with normal individuals [25]. More recent study [21] contradicted the earlier finding and observed that serum IgG and IgA are not significantly elevated in oral cancers and hence not to be used as a good surrogate marker for diagnosis and prognosis.

Previous reports of immunoglobulin levels in breast cancer patients are conflicting [26]-[32] and numerous responses of immune disturbances have been associated with breast cancer due to possible defect in immune mechanisms [20]. A study observed marked increased IgM in breast fluid of breast cancer pa- 
tients prior to mastectomy with decrease in IgA levels [29]. Similar significant reductions in IgA and IgG in breast tissues were observed by Robert et al. [26]. The total immunoglobulin levels and IgG levels were found to correlate with plasma cell infiltration. The previous studies neither discussed the staging of the breast cancer patients, the effect of treatment nor used age-matched controls. Our study was undertaken to compare the major serum immunoglobulin levels (IgA, IgG, and IgM) in patients with malignant and pre-malignant breast conditions of the breast across disease stages and treatment groups.

\section{Materials and Methods}

\subsection{Subjects and Sampling}

This is a prospective longitudinal study conducted between February 2015 and June; 2017 on treatment-naive female patients age range from 30 to 68 years with breast tumour and referred to the Oncology Units of Departments of Surgery of University of Nigeria Teaching Hospital, Enugu and Federal Teaching Hospital, Abakaliki (both in Eastern-Nigeria). Diagnosis and staging were clinically and pathologically confirmed. The studied individuals were grouped into three.

Group I: Patients group-included 59 breast cancer patients; due to small sample size this group was further divided into early stage breast cancer (stages 1 $\& 2, \mathrm{~N}=24$ ) and advanced stage breast cancer (stages $3 \& 4, \mathrm{~N}=35$ ) based on Tumour Node Metastasis (TNM) classification.

Group II: Patients control-included 20 patients with benign breast tumour (BBT).

Group III: Normal control-20 apparently healthy age/sex matched (AHMC) female volunteers without history or clinical evidence of breast lesion drawn from hospital and university communities.

Sampling was by self-selection consequent to the approval of the study protocol by the respective Hospitals Ethical Committee, informed written consent obtained from the individuals and exclusion criteria applied. Structured questionnaire on socio-demographic factors were served, explained and interpreted in local Igbo language for the patients that are not literate. Breast tumour patients who received any therapy prior to diagnosis (surgery/radiotherapy/chemotherapy), previous history of malignancy and history of any other medical illness, which would otherwise limit the survival of the patient in the absence of malignancy, were excluded. All patients underwent standard treatment modalities (neoadjuvant or adjuvant chemotherapy, radiotherapy, chemoradiation, and/or surgery; depending on the stage of presentation. In breast cancer (BC) patients and benign breast tumour (patients control groups), blood samples were collected before any form of treatment and two more samples at 3 and 6 months interval. In apparently healthy sex/age-matched control, one blood sample was taken from each participant. The samples were allowed to clot and retract, centrifuged at $5000 \mathrm{rpm}$, serum separated and stored at $-20^{\circ} \mathrm{C}$ until analyzed. 


\subsection{Asay Methods}

IgG and IgM: Solid phase capture sandwich ELISA (kits sourced from Diagnostic Automation/Cortz Diagnostics, Inc., AccuDiagTM Cat\# 1803-9, Calabasa, CA 91302, USA) were adopted for both IgG and IgM estimation. The molecules of IgG or IgM respectively are sandwiched between two monoclonal antibodies; one coated to the bottom of the wells of microtiter plates and the other linked to the horseradish peroxidase (enzyme conjugate). After incubation and washing, the enzymatic reaction develops a colour which is proportional to the amount of IgG or IgM molecules present in the assay.

IgA: The immunoturbidimetric assay method was adopted (kit was sourced from Randox Laboratories, UK; Cat \#1A2447) for IgA estimation. The principle is based on the turbidimetric specific reaction which occurs between the anti-IgA polyclonal antiserum and its corresponding antigen in optimal $\mathrm{pH}$ conditions and in the presence of polyethyleneglycol polymer (PEG). The change in turbidity of the immunocomplex is proportional to the concentration of the analyte in the sample.

\subsection{Statistical Analysis}

Data were analyzed using statistical package for Social Sciences (SPSS) software. Statistical significance was set at $\mathrm{p}<0.05$. Dunn's multiple comparison tests and Kruskall-Wallis analysis of variance were applied for measuring the differences between disease and treatment groups. GraphPad prism version 6.0 (by GraphPad, USA) was used for the graphs.

\section{Results}

The summary of the results statistic of different classes of immunoglobulins (IgG, IgM and IgA) levels across disease stages and treatment groups is presented in Table 1. At pre-treatment category the median values of IgG were $10.33 \mathrm{~g} / \mathrm{L}, 10.7 \mathrm{~g} / \mathrm{L}, 9.65 \mathrm{~g} / \mathrm{L}, 9.95 \mathrm{~g} / \mathrm{L}$ for early stage breast cancer (ESBS), advanced stage breast cancer (ASBC), benign breast tumour (BBT) and apparently healthy matched control (AHMC) respectively.

Mean pre-treatment IgG values of $10.33 \pm 0.82 \mathrm{~g} / \mathrm{L}, 11.29 \pm 3.36 \mathrm{~g} / \mathrm{L}, 9.9 \pm$ $0.64 \mathrm{~g} / \mathrm{L}$ and $10.13 \pm 0.6 \mathrm{~g} / \mathrm{L}$ were recorded in ESBC, ASBC and BBT samples respectively against $10.13 \pm 0.6 \mathrm{~g} / \mathrm{L}$ observed in apparently healthy age/sex matched control group (normal range $5-18 \mathrm{~g} / \mathrm{L}$ ). Also mean serum IgG values at 3 months and 6 months ESBC were $10.19 \pm 1.01 \mathrm{~g} / \mathrm{L}$ and $11.35 \pm 3.42 \mathrm{~g} / \mathrm{L}$ compared to $10.26 \pm 1.40 \mathrm{~g} / \mathrm{L}$ and $10.19 \pm 0.71 \mathrm{~g} / \mathrm{L}$ recorded in ASBC respectively. Likewise the IgM values did not differ significantly across the disease and treatment groups. Mean serum IgM values of $5.94 \pm 2.94 \mathrm{~g} / \mathrm{L}, 5.26 \pm 1.90 \mathrm{~g} / \mathrm{L}$ and $5.03 \pm 2.03 \mathrm{~g} / \mathrm{L}$ were observed in pre-treatment, 3 months and 6 months post-treatment in ASBC respectively. Similar normal and close ranges in mean values were seen inIgA across disease and treatment groups (Table 1).

In comparison of different stages of disease stage and treatment groups, there 
Table 1. Summary of Statistics for immunoglobulins level across disease and treatment groups.

\begin{tabular}{|c|c|c|c|c|c|c|c|}
\hline Category & Variables & Minimum & Maximum & Median & Mean & Std. Dev. & SE \\
\hline & IgG & 9.1 & 11.6 & 10.33 & 10.33 & 0.82 & 0.24 \\
\hline \multirow[t]{3}{*}{ Pre-treatment ESBC } & $\operatorname{IgM}$ & 2.3 & 7.4 & 4.68 & 4.68 & 1.39 & 0.40 \\
\hline & $\operatorname{IgA}$ & 0.2 & 1.0 & 0.56 & 0.56 & 0.22 & 0.06 \\
\hline & IgG & 0.88 & 12.22 & 10.19 & 10.19 & 1.01 & 0.29 \\
\hline \multirow[t]{3}{*}{$\begin{array}{c}3 \text { months } \\
\text { post-treatment ESBC }\end{array}$} & $\operatorname{IgM}$ & 1.2 & 8.9 & 5.13 & 5.13 & 2.28 & 0.66 \\
\hline & $\operatorname{IgA}$ & 0.2 & 0.9 & 0.56 & 0.56 & 0.23 & 0.07 \\
\hline & $\operatorname{IgG}$ & 8.7 & 21.1 & 11.35 & 11.35 & 3.43 & 1.03 \\
\hline \multirow{3}{*}{$\begin{array}{l}6 \text { months } \\
\text { post-treatment ESBC }\end{array}$} & $\operatorname{IgM}$ & 2.2 & 8.2 & 4.69 & 4.69 & 1.65 & 0.50 \\
\hline & $\operatorname{Ig} A$ & 0.4 & 0.8 & 0.60 & 0.60 & 0.17 & 0.05 \\
\hline & $\operatorname{IgG}$ & 8.8 & 21.1 & 10.7 & 11.29 & 3.36 & 0.75 \\
\hline \multirow[t]{3}{*}{ Pre-treatment ASBC } & $\operatorname{IgM}$ & 2.3 & 13.2 & 4.80 & 5.94 & 2.94 & 0.66 \\
\hline & $\operatorname{IgA}$ & 0.3 & 1.0 & 0.70 & 0.65 & 0.19 & 0.04 \\
\hline & IgG & 6.7 & 13.1 & 10.35 & 10.26 & 1.40 & 0.31 \\
\hline \multirow[t]{3}{*}{$\begin{array}{l}3 \text { months } \\
\text { post-treatment ASBC }\end{array}$} & $\operatorname{IgM}$ & 2.2 & 8.4 & 5.50 & 5.26 & 1.90 & 0.43 \\
\hline & $\operatorname{Ig} \mathrm{A}$ & 0.3 & 1.0 & 0.65 & 0.67 & 0.20 & 0.05 \\
\hline & $\operatorname{IgG}$ & 8.4 & 11.4 & 10.15 & 10.19 & 0.71 & 0.19 \\
\hline \multirow[t]{3}{*}{$\begin{array}{l}6 \text { months } \\
\text { post-treatment ASBC }\end{array}$} & $\operatorname{IgM}$ & 1.6 & 7.8 & 4.95 & 5.03 & 2.03 & 0.54 \\
\hline & $\operatorname{IgA}$ & 0.4 & 1.0 & 0.60 & 0.62 & 0.16 & 0.04 \\
\hline & IgG & 9.1 & 10.9 & 9.65 & 9.9 & 0.64 & 0.20 \\
\hline \multirow[t]{3}{*}{ Pre treatment BBT } & $\operatorname{IgM}$ & 2.8 & 6.1 & 5.40 & 5.21 & 0.95 & 0.31 \\
\hline & $\operatorname{Ig} \mathrm{A}$ & 0.4 & 1.1 & 0.50 & 0.62 & 0.21 & 0.07 \\
\hline & $\operatorname{IgG}$ & 8.8 & 10.7 & 9.60 & 9.7 & 0.57 & 0.19 \\
\hline \multirow{3}{*}{$\begin{array}{l}3 \text { months } \\
\text { post-treatment BBT }\end{array}$} & $\operatorname{IgM}$ & 4.8 & 6.1 & 5.20 & 5.43 & 0.55 & 0.18 \\
\hline & $\operatorname{IgA}$ & 0.5 & 1.0 & 0.80 & 0.81 & 0.18 & 0.06 \\
\hline & IgG & 9.1 & 11.0 & 9.95 & 10.13 & 0.6 & 0.19 \\
\hline \multirow[t]{2}{*}{ AHMC } & $\operatorname{IgM}$ & 3.2 & 10.7 & 6.25 & 6.19 & 2.48 & 0.79 \\
\hline & IgA & 0.3 & 0.7 & 0.50 & 0.49 & 0.12 & 0.04 \\
\hline
\end{tabular}

ESBC: early stage breast cancer, ASBC: advanced stage breast cancer, BBT: benign breast tumour, AHMC: apparently healthy matched control.

were no significant difference ( $\mathrm{p}>0.05$ ) in $\operatorname{IgG}, \operatorname{IgM}$ and IgA respectively Figures 1-3). Similar results were recorded when the breast cancer cases were condensed into one group.

The results of some demographic and anthropologic risk factors showed (Table 2) that the majority (59\%) of breast cancer patients was diagnosed at advanced stage of the disease and the median age at diagnosis was 51 years with prevailing low level of education (66\%) and low income (47\%). Results also 


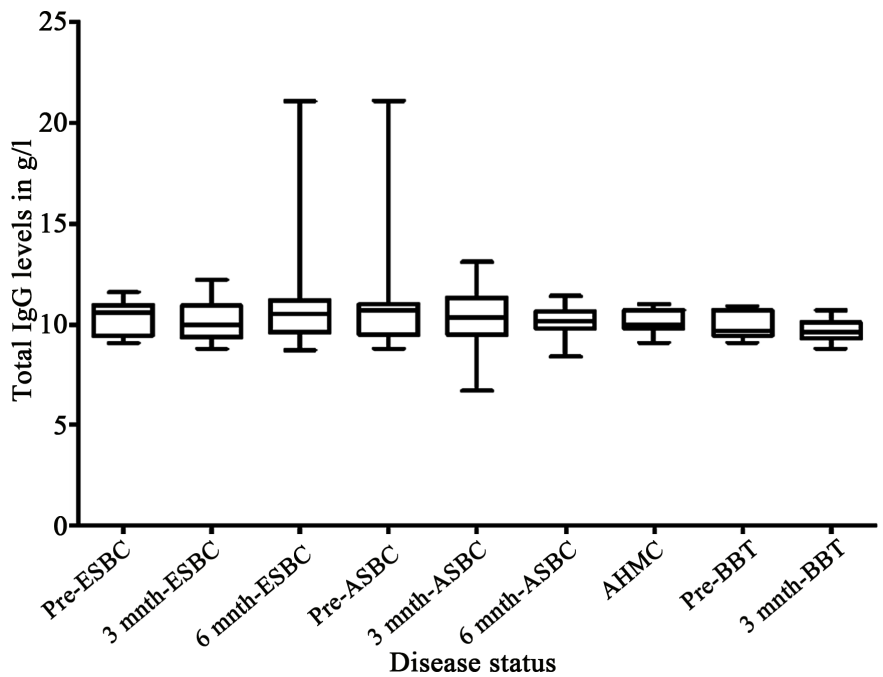

Figure 1. Comparison of total serum IgG levels across the disease and treatment groups $(\mathrm{P}$ value $=0.57)$. Key: ESBC-Early stage breast cancer, ASBC-Advanced stage breast cancer, AHMC-Apparently healthy control, BBT_Benign breast tumour.

Table 2. Categories of risk factors for breast cancer.

\begin{tabular}{|c|c|c|c|}
\hline Variable & Level of risk for $\mathrm{BC}^{*}$ & $\mathbf{n}$ & $\%$ \\
\hline \multicolumn{4}{|l|}{ Age at diagnosis $(\mathrm{n}=59)$} \\
\hline 35 - 45 years & High & 15 & 25 \\
\hline$\geq 46$ years & Medium & 44 & 75 \\
\hline$<35$ years & Low & 0 & 0 \\
\hline \multicolumn{4}{|c|}{ History of breast cancer in family $(n=59)$} \\
\hline First-degree relative & High & 5 & 9 \\
\hline Second-degree relative & Medium & 8 & 14 \\
\hline No relative & Low & 46 & 78 \\
\hline \multicolumn{4}{|l|}{ Educational level $(\mathrm{n}=59)$} \\
\hline High level (Tertiary) & High & 20 & 34 \\
\hline Low level (Primary \& Secondary) & Medium & 39 & 66 \\
\hline \multicolumn{4}{|l|}{ Income $(\mathrm{n}=59)$} \\
\hline High class & High & 11 & 19 \\
\hline Meddle class & Medium & 20 & 34 \\
\hline Low class & Low & 28 & 47 \\
\hline \multicolumn{4}{|l|}{ Body mass index $\left(\mathrm{kg} / \mathrm{m}^{2}\right)$} \\
\hline *>30 (highest quintiles) & High (obese) & 37 & 63 \\
\hline 27 - 30 (within quintiles) & Medium & 712 & \\
\hline$* * 23-26$ (low quintiles) & Low & 13 & 22 \\
\hline$* * *<23$ (lowest quintile) & Low & 23 & \\
\hline
\end{tabular}

${ }^{*}$ Evaluation according to interpretations for breast cancer risk factors and categories. ${ }^{*}$ Overweight BMI category. ${ }^{* *}$ Desirable healthy BMI. ${ }^{* *}$ Underweight BMI category. 


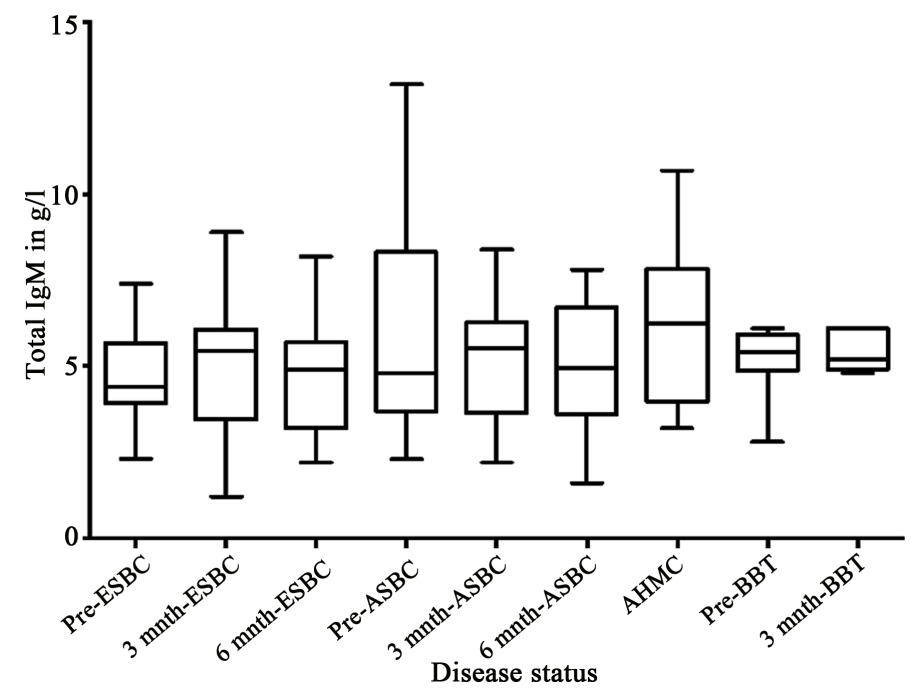

Figure 2. Comparison of total serum IgM levels across the disease and treatment groups $(\mathrm{P}$ value $=0.86)$. Key: ESBC-Early stage breast cancer, ASBC_Advanced stage breast cancer, AHMC-Apparently healthy control, BBT-Benign breast tumour.

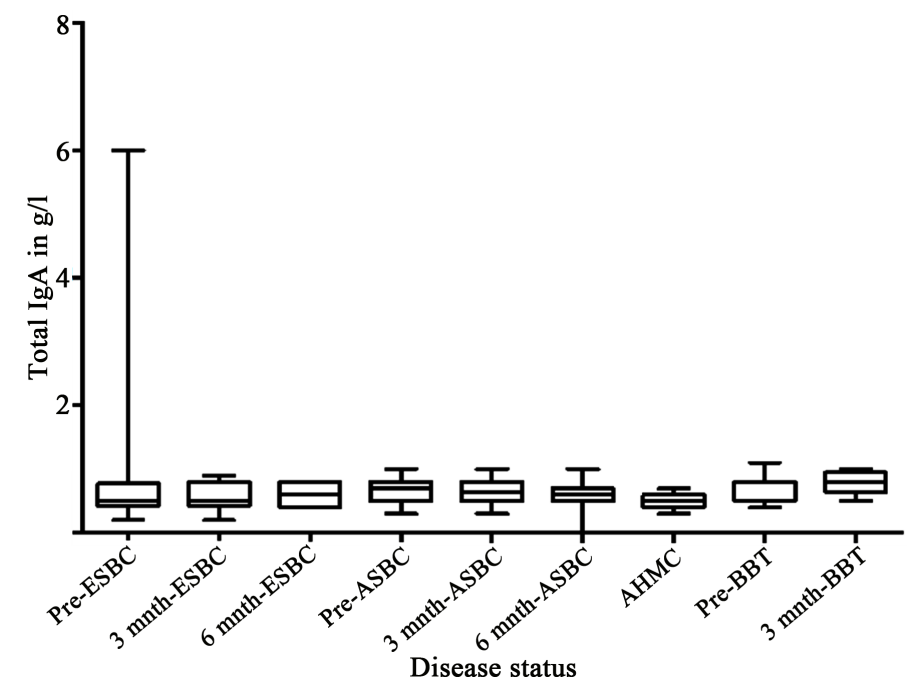

Figure 3. Comparison of total serum IgA levels across the disease and treatment groups $(\mathrm{P}$ value $=0.11)$. Key: ESBC—early stage breast cancer, ASBC—advanced stage breast cancer, AHMC-apparently healthy control, BBT_Benign breast tumour.

showed that $78 \%$ of the cases did not have any history of cancer in their families and $63 \%$ of the cases had body mass index values suggestive of obesity ( $>30$ $\mathrm{kg} / \mathrm{m}^{2}$ ).

\section{Discussion}

The assay of serum immunoglobulins in human cancers has been reported by various workers such as carcinoma of cervix [21], pancreatic cancer [22], primary liver carcinoma [23], squamous cell carcinoma [24] and breast cancer [26]-[31], with varied findings and opinions. In oral cancer patients, previous investigations of serum immunogloblin levels showed an increase in IgM, IgA, 
IgE, and IgG when compared with normal individuals. The work of Kemp et al. [21] contradicted the earlier finding and observed that serum IgG and IgA are not significantly elevated in oral cancers and hence not to be used as a good surrogate marker for diagnosis and prognosis. Increased levels of IgM in cancer patients have been found to correlate with the clinical stages. On the contrary a report from India [33] found no significant increase in IgM levels with progression of disease.

Numerous responses of immune disturbances have been associated with breast cancer and immunoglobulins are produced not only by B lymphocytes and plasma cells but by other nonlymphoid lineage cells like cancer cells. This may explain the role of immune defect in immunoglobulin metabolism and pathogenesis of breast cancer. Expression of different classes of immunoglobulins has been found to correlate with malignancy [25] [33] [34] and may be associated with genesis, development and prognosis of the cancer as evidenced and recognized by the American Joint Committee on Cancer. Markedincreasein IgM was found in breast fluid in breast cancer patients prior to mastectomy with decrease in IgA and IgG levels [29] and IgG levels found to correlate with plasma cell infiltration [26].

In this study serum immunoglobulins (IgG, IgM and IgA) were evaluated in women with malignant and benign breast conditions. Solid phase capture sandwich ELISA that has been found to be sensitive was used for the estimation of IgG and IgM while turbidimetric specific reaction which occurs between the anti-IgA polyclonal antiserum and its corresponding antigen in optimal $\mathrm{pH}$ conditions and in the presence of polyethyleneglycol polymer (PEG) was adapted for IgA. There were no statistical significant differences in total serum IgG, IgM and IgA across disease stages and treatment groups when compared.

During cancer progression, the level of immunoglobulins and complements are altered markedly to compensate for changing environment of cancer cells. Variations have been found in the level of these defense proteins both in the blood and tissues concerned. Robert et al. [26] estimated the immunoglobulin levels (IgG, IgM and IgA) in protein extracts of malignant and benign tumour of breast and in normal tissues from cancer bearing breast. The serum levels of IgG, IgA, IgE and IgM pre-operatively and post operatively at 3 months, 1 year and 2 years were analyzed. Patients who have undergone modified radical mastectomy for breast cancer showed alterations in serum immunoglobulin concentration after receiving full cycle of chemotherapy. This is in disparity with the present findings though in different racial/ethnic background. We made use of more sensitive method for immunoglobulin estimation other than the immunodifussion method used by the previous researchers.

Comparative analysis in serum immunoglobulin level between patient with breast cancer and benign breast disease were studied by other researchers [35] [36] with varied opinions. Schauenstein et al. [35] observed significant decrease in percentage IgG1 accompanied by an increase in percentage IgG2 in total serum. In a similar work; Kronberger et al. [37] studied the diagnostic value of the 
decrease in percentage of immunoglobulin G1 (\%IgG1) in breast cancer with special emphasis on early tumor stages. The IgG1 and total IgG were preoperatively measured in the sera of a total of 801 individuals using a modified quantitative affinity chromatography. The differences in mean values were highly significant between the breast cancer, benign breast disease and apparently healthy control. They suggested that significant decrease of percentage IgG1 in total serum IgG was able to distinguish patients with breast cancer of more than $5 \mathrm{~mm}$ in diameter from healthy controls and patients with benign breast diseases.

Most of these works were done on patients of different ethnic/racial and environmental background and this could possibly explain the different paradigm of the present study. Immunoglobulin subclasses were not however analyzed in this study to ascertain possible association with progression of breast cancer. There is need therefore for further work on the clinical utility of immunoglobulin subclasses in the management of breast cancer.

Despite the improvement in health facilities; most of the patients in this study presented at advanced stages of the disease when little or no benefit can be derived from any form of therapy. This is indeed is worrisome and a major challenge and could be attributed to poverty, lack of free screening centers and ignorance giving room for incorporeal interpretation for such health problems. The knowledge, attitude and practice of breast cancer screening was previously studied by Chukwurah et al. [38] in the same environment and found to be poor. Unfortunately early detection through mammography, routine and self-breast examinations which are so effective in educated communities are seldom applicable in poorly educated ones in whom the carcinomas commonly present late; intensive education and training of women groups by the government and non-governmental organization should be encouraged and extended to rural communities.

The median age at diagnosis for the female breast cancer patients studied was 51 years. This is similar to the reports in Nigeria [39], Anzanian women [40] and in African-Americans [41], but higher than 29.1 years found among Indian women [42]. The majority (75\%) of the patients under study were 46 years and older at diagnosis, which is older than the age range of 35 to 45 years, found to be the typical age at diagnosis for most African women by various researchers [40] [43]. The age at the time of diagnosis determines risk (the earlier a woman develops a first primary breast cancer in her lifetime, the greater the risk of developing a second breast cancer [44]. Only $25 \%$ of the current patients were diagnosed before the age of 45 years which corresponds to a high risk for breast cancer recurrence. However, the age of studied subjects across disease groups did not differ statistically. This implies that screening for breast cancer ought to start at earlier age ( 25 years) in order to aim for early detection and treatment and thus a better probability of survival.

A woman is at an increased risk if her blood relatives on either her mother or father's side have had cancers of the breast [45] and/or ovaries [46]. The majori- 
ty $(78 \%)$ of the patients in the present study reported having no relatives diagnosed with any type of cancer, which corresponds with a low risk [47]. Nigerian patients [48] and American women (both African-American and white) with breast cancer [49] were reported to be more likely to have a first-degree family history of breast cancer than their controls. Only $9 \%$ of the present patients had first degree relatives with cancer which placed them in a high risk category compared to $19.0 \%$ of Californian patients [50]. The reasons for low prevalence of first-degree and second-degree family history of cancer may be due to poor recording of deaths, tendency of secrecy regarding family history, incorporeal believe on every sickness and dirt of autopsy report on every patient that died in the hospital. Effort should be geared towards adequate information and education of the populace on the importance of knowing the cause of every death and the implications in health policies and management.

Level of education has been described a risk factor in breast cancer development [51]. Findings in Filipino women [52] indicated that the risk is almost double for women who had received a tertiary education compared with those who received only a minimal education, or primary and/or high school certificates, since time spent in getting educated followed by building a career contribute to delay in marriage and possibly conception [53]. The level of education has been suggested to affect other factors associated with breast cancer risk-including reproductive patterns (parity and age at first birth) and lifestyle behaviours (physical activity and diet) [51]. In this study the majority (66\%) of the patients had a low level of education (defined in this study as having a primary or high school certificate) and thus a low risk for breast cancer development. Similar results were also found among Bahraini women with breast cancer [54] where $78.0 \%$ had low levels of education.

Level of income has also been associated with risk of breast cancer development [55] (Samaras, 2010). In this study a low income level referred to a low or working class. About $47 \%$ of the study subjects had a low level of income placing them into a low risk category for breast cancer development. This finding is in disparity with only $9.0 \%$ found in Californian patients who had reported their status as "poor" (working class) or "lower middle" class [50]. Most of the low income patients also had a low education level (primary/high school certificate) and did menial jobs such as hawking, laborers, petit trading, messengers and cleaners. Approximately $34 \%$ of the current patients were of medium income class while only $19 \%$ were of high income placing them under high risk category.

Obesity has been associated with increased risk of breast cancer [43] [48]. Central adiposity has a higher risk of breast cancer than fat distributed over the hips, buttocks, and lower extremities. The risk is increased through multiple hormonal and metabolic changes. Reports have shown variations in the prevalence of obesity in developing countries [43] [48] [55]. In the present study, most of the patients (63) presented with BMI above $30 \mathrm{~kg} / \mathrm{m}^{2}$ : placing them in high risk category for breast cancer. 
The incidence of breast cancer in this environment is increasing. This is partly a result of the changing demographic profile, acquisition of "western" lifestyle, and the changing socioeconomic profile of the country. There is need therefore for shift in the overall structure of our dietary pattern, physical activities and overall health.

There is need for development of measures for early detection of the disease through mass enlightenment and free breast cancer screening at all levels (targeting women organizations and schools) and encouraging regular self-breast examination. The silent nature of breast cancer at onset makes it difficult to be detected early, demanding improved, sensitive and affordable screening procedures. Advocacy and evidence based policies aimed at prevention through education, nutrition; environmental and general health should be encouraged and prioritized.

The prime limitation encountered was that of follow up for the repeat sampling after various forms of treatment especially in patients with benign breast tumour were over $50 \%$ were lost before 6 months. Some patients resorted to unorthodox and spiritual healing and some traveled overseas.

\section{Conclusion}

Results suggest that serum immunoglobulin (IgG, IgM and IgA) levels are of limited value in surveillance of breast cancer in our environment. Based on our findings, it could also be concluded that low level of education and low income are among the risk factors. Advocacy and evidence based policies aimed at prevention through education, nutrition; environmental and general health should be encouraged and prioritized.

\section{Conflicts of Interest}

The authors declare no conflicts of interest regarding the publication of this paper.

\section{References}

[1] Easton, D.F. (2005) Study Shows Women of African Ancestry Diagnosed with More Virulent form of Breast Cancer. The University of Chicgo Chronicle, 24, 1-3.

[2] Fregene, A. and Newman, L.A. (2005) Breast Cancer in Sub-Saharan Africa. How Does It Relate to Breast Cancer in African-American Women. Cancer, 103, 1540-1550. https://doi.org/10.1002/cncr.20978

[3] Kruger, W.M. and Apffelstaedt, J.P. (2007) Young Breast Cancer Patients in the Developing World: Incidence, Choice of Surgical Treatment and Genetic Factors. South African Family Practice, 49, 18-24. https://doi.org/10.1080/20786204.2007.10873634

[4] Atoyebi, O.A., Atimomo, C.E., Adesanya, A.A., Beredugo, B.K. and da Rocha-Afodu, J.T. (1997). An Appraisal of 100 Patients with Breast Cancer Seen at Lagos University Teaching Hospital. Nigerian Quarterly Journal of Hospital Medicine, 7, 104-108.

[5] Anyanwu, S.N. (2000) Breast Cancer in Eastern Nigeria: A Ten Year Review. West 
African Journal of Medicine, 19, 120-125.

[6] Adetifa, F.A. and Ojikutu, R.K. (2009) Prevalence and Trends in Breast Cancer in Lagos State, Nigeria. An International Multi-Disciplinary Journal, Ethiopia, 3, 1-15.

[7] Adisa, C.A., Eleweke, N., Alfred, A.U., Cambell, M.J., Sharma, R., Nseyo, O., Tandon, V., Mukhfar, R., Greninger, A., Di Risi, J. and Esserman, L.J. (2012) Biology of Breast Cancer in Nigerian Women: A Pilot Study. Annals of African Medicine, 11, 169-175. https://doi.org/10.4103/1596-3519.96880

[8] Hansen, M.H., Nielsen, H. and Ditzel, H.J. (2001) The Tumor-Infiltrating B Cell Response in Medullary Breast Cancer Is Oligoclonal and Directed against the Autoantigen Actin Exposed on the Surface of Apoptotic Cancer Cells. Proceedings of the National Academy of Sciences of the United States of America, 98, 12659-12664. https://doi.org/10.1073/pnas.171460798

[9] Zheng, H., Li, M., Ren, W., Zeng, L., Liu, H.D., et al. (2007) Expression and Secretion of Immunoglobulin Alpha Heavy Chain with Diverse VDJ Recombinations by Human Epithelial Cancer Cells. Molecular Immunology, 44, 2221-2227. https://doi.org/10.1016/j.molimm.2006.11.010

[10] Cazet, A., Julien, S., Bobowski, M., Burchell, J. and Delannoy, P. (2010) Tumour-Associated Carbohydrate Antigens in Breast Cancer. Breast Cancer Research, 12, 204. https://doi.org/10.1186/bcr2577

[11] Edge, S.B., Byral, D.R., Compton, C.C., Fritz, A.G., Greene, F.L. and Trotti, A. (2010) AJCC Cancer Staging Manual. 7th Edition, Springer, New York, 49-56.

[12] Anderson, K.S. and LaBaer, J. (2005) The Sentinel within: Exploiting the Immune System for Cancer Biomarkers. Journal of Proteome Research, 4, 1123-1133. https://doi.org/10.1021/pr0500814

[13] Isik, A., Peker, K., Firat, D., Yilmaz, B., Sayer, I., Idiz, O., Caker, C., Demirylmaz, I. and Yilmaz, I. (2014) Impotance of Metastatic Lymph Node Reaction in Non-Metastatic, Lymph Node-Invaded Colon Cancer: A Clinical Trial. Medical Science Monitor, 20, 1369-1375. https://doi.org/10.12659/MSM.890804

[14] Isik, A., Okan, I., Firat, D., Yilmaz, B., Akcakava, A. and Sahin, M. (2014) A New Prognostic Strategy for Gastric Carcinoma: Albumin Level and Metastatic Lymph Node Ratio. Minerva Chirurgica, 69, 147-153.

[15] Chukwurah, E.F., Emele, F.E., Iyare, F.E., Nwigwe, C.G. and Ogbodo, S.O. (2016) Evaluation of Circulating Immune Complexes in Patients with Malignant and Pre-Malignant Disease Conditions of the Breast in South-Eastern Nigeria. Journal of Disease and Global Health, 5, 211-217.

[16] Emele, F.E. and Chukwurah, E.F. (2017) Evaluation of Serum Cancer Antigens (CA 15-3 and CA 27.29) and Circulating Immune Complexes as Important Tools in the Management of Breast Cancer in Nigeria. The Journal of Immunology, 198, 76.1.

[17] Chukwurah, E.F., Emele, F.E. and Iyare, F.E. (2018) Breast Cancer in Nigerian Women: Evaluating the Utility of Circulating Immune Complexes and Cancer Antigens (CA 15-3 and CA 27.29) in Disease Surveillance. Research Journal of Immunology, 11, 7-14.

[18] Chen, Z., Qiu, X. and Gu, J. (2009) Immunoglobulin Expression in Non-Lymphoid Lineage and Neoplastic Cells. American Journal of Pathology, 174, 1139-1148. https://doi.org/10.2353/ajpath.2009.080879

[19] Wang, J., Lin, D., Peng, H., Huang, Y., Huang, J. and Gu, J. (2013) Cancer-Derived Immunoglobulin G Promotes Tumor Cell Growth and Proliferation through Inducing Production of Reactive Oxygen Species. Cell Death and Disease, 4, e945. 
https://doi.org/10.1038/cddis.2013.474

[20] Alsabti, E.A. (1979) Serum Immunoglobulins in Breast Cancer. Journal of Surgical Oncology, 11, 129-133. https://doi.org/10.1002/jso.2930110206

[21] Kemp, T.J., Safaeian, M., Miner, S., Williams, M.C., Rodrignez, A.C., Herrco, R., Hildesheim, A. and Pinta, L.A. (2012) Oral Immunoglobulin Levels Are Not a Good Surrogate for Cervical Immunoglobulin Levels. Frontiers in Oncology, 2, 61. https://doi.org/10.3389/fonc.2012.00061

[22] Raina, A., Krasinska, A.M., Greer, J.R., Lamb, J., Fink, E., Moser, A.J., Zeh, H.J., Slivka, A. and Whitcomb, D.C. (2008) Serum Immunoglobulin G Fraction 4 Levels in Pancreatic Cancer: Elevation Not Associated with Autoimmune Pancreatitis. Archives of Pathology \& Laboratory Medicine, 132, 48-53.

[23] Ipp, T., Macnab, G.M., Geddes, E.W. and Keo, M.C. (1975) Serum Immunoglobulin Levels in Primary Liver Cancer: Relationship to Underlying Cirrhosis and Hepatitis-B (Surface Antigenemia). British Journal of Cancer, 32, 509-511. https://doi.org/10.1038/bjc.1975.253

[24] Neuchrist, C., Kornfehl, J., Grasl, M., Lassman, N., Kraft, D. and Ehrenberger, K. (1994) Distribution of Immunoglobulin in Squamous Cell Carcinoma of Head and Neck. International Archives of Allergy \& Immunology, 104, 97-100.

[25] Khana, S. and Karjodkar, F.R. (2006) Circulating Immune Complexes and Trace Elements (Copper, Iron and Selenium) as Markers in Oral Precancer and Cancer: A Randomised Controlled Clinical Trial. Head and Face Medicine, 2, 33. https://doi.org/10.1186/1746-160X-2-33

[26] Roberts, M.M., Bass, E.M., Wallace, I.J. and Stevenson, A. (1993) Local Immunoglobulin Production in Breast Cancer. British Journal of Cancer, 27, 269-275. https://doi.org/10.1038/bjc.1973.33

[27] Roberts, M.M., Bathgate, E.M. and Stevenson, A. (1975) Serum Immunoglobulin Levels in Patients with Breast Cancer. Cancer, 36, 221-224.

https://doi.org/10.1002/1097-0142(197507)36:1<221::AID-CNCR2820360124>3.0.C $\underline{\mathrm{O} ; 2-\mathrm{P}}$

[28] Wang, D.Y., Goodwin, P.O., Bulbrook, R.D., Hayward, J.L., Abe, O., Utsunomiya, J. and Kumaoka, S. (1977) Possible Relationship of Plasma IgA, IgG and IgM to Breast Cancer in British and Japanese Women. European Journal of Cancer, 13, 1405-1409. https://doi.org/10.1016/0014-2964(77)90153-0

[29] Petrakis, L., Doherty, M., Lee, R., Mason, L., Pawson, S, Hunt, T.K. and Schweitzer, R. (1977) Immunoglobulin Levels in Breast Fluids of Women with Breast Cancer. Clinical Immunology \& Immunopathology, 7, 386-393. https://doi.org/10.1016/0090-1229(77)90073-3

[30] Norum, L.F., Erikstein, B. and Nustad, K. (2001) Elevated CA 125 in Breast Cancer-A Sign of Advance Disease. Tumour Biology, 22, 223-228. https://doi.org/10.1159/000050620

[31] Park, B.W., Oh, J.W., Kim, J.H., Park, S.H., Kim, K.S., Kim, J.H. and Lee, C.S. (2007) Preoperative CA 15-3 and CEA Serum Levels as Predictor of Breast Cancer. Annals of Oncology, 19, 675-681. https://doi.org/10.1093/annonc/mdm538

[32] Charlotte, W., Bo, B., Ola, B., Dorthe, G. and Bo, J. (2013) Primary Breast Cancer Tumours Contain High Amounts of IgA1 Immunoglobulin: An Immunohistochemical Analysis of a Possible Carrier of the Tumour-Associated Tn Antigen. PLoS ONE, 8, e61749.

[33] Rajendran, R., Sugathan, C.K., Remani, P., Ankathil, R. and Vijayakumar, T. (1986) Cell Mediated and Humoral Immune Responses in Oral Submucous Fibrosis. Can- 
cer, 58, 2628-2631.

https://doi.org/10.1002/1097-0142(19861215)58:12<2628::AID-CNCR2820581214> 3.0.CO;2-Z

[34] Yang, B., Ma, C., Chen, Z., Yi, W., McNutt, M., Wang, Y., Korteweg, C. and Gu, J. (2013) Correlation of Immunoglobulin G Expression and Histological Subtype and Stage in Breast Cancer. PLoS ONE, 8, e58706. https://doi.org/10.1371/journal.pone.0058706

[35] Schauenstein, E., Rabi, H., Steinschifter, W., Hirschmann, C., Estelberger, W. and Schauenstein, K. (1997) Selective Decrease of Serum Immunoglobulin G1 as a Marker of Malignant Transformation in Colorectal Tissue. Cancer, 79, 1486-1486. https://doi.org/10.1002/(SICI)1097-0142(19970415)79:8<1482::AID-CNCR6>3.0.C $\underline{\mathrm{O} ; 2-\mathrm{D}}$

[36] Ahmed, H.U., Zacharakis, E., Dudderidge, T., Armitage, J.N., Scott, R., Calleary, J., Illing, R., Kirkham, A., Freeman, A., Ogden, C., Allen, C. and Emberton, M. (2009) High-Intensity-Focused Ultrasound in the Treatment of Primary Prostate Cancer: The First UK Series. British Journal of Cancer, 101, 19-26. https://doi.org/10.1038/sj.bjc.6605116

[37] Kronberger, L., Steinschifter, W., Weblacher, M., Estelberger, W., Liebmann, P.M., Rabi, H., Smola, M., Lax, S.F., Mischinger, H.J. and Schauenstein, E. (2000) Selective Decrease of Serum Immunoglobulin G1 as Marker for Early Stages of Invasive Breast Cancer. Breast Cancer Research and Treatment, 64, 193-199. https://doi.org/10.1023/A:1006450205698

[38] Chukwurah, E.F., Uro-Chukwu, H.C. and Uneke, C.J. (2017) Assessment of the Knowledge, Attitude and Practice of Breast Cancer Screening among Female Undergraduate Students of Ebonyi State University. Congress Oral Communication Abstracts: 41st West African College of Physicians Annual Congress, Dakar Senegal.

[39] Adebamowo, C.A. and Adekunle, O.O. (1999) Case-Control Study of the Epidemiological Risk Factors for Breast Cancer in Nigeria. British Journal of Surgery, 86, 665-668. https://doi.org/10.1046/j.1365-2168.1999.01117.x

[40] Rambau, P.F., Chalya, P.L., Manyama, M.M. and Jackson, K.J. (2011) Pathological Features of Breast Cancer Seen in North-Western Tanzania: A Nine Years Retrospective Study. British Medical Council Research Notes, 4, 214.

[41] Palmer, J.R., Wise, L.A., Horton, N.J., Adams-Campbell, L.L. and Rosenberg, L. (2003) Dual Effect of Parity on Breast Cancer Risk in African-American Women. Journal of the National Cancer Institute, 95, 478-483. https://doi.org/10.1093/jnci/95.6.478

[42] Puri, S., Mangat, C., Bhatia, V., Kalia, M., Sehgel, A. and Kaur, A.P. (2009) Awareness of Risk Factors and Aspects of Breast Cancer among North Indian Women. The Internet Journal of Health, 8, 112.

[43] Adebamowo, C., Ogundiran, T.O., Adenipekun, A.A., Oyesegun, R.A., Campbell, O.B., Akang, E.E., Rotimi, C.N. and Olopade, O.I. (2003) Waist-Hip-Ratio and Breast Cancer in Urbanize d Nigerian Women. Breast Cancer Research, 5, 18-24. https://doi.org/10.1186/bcr567

[44] Chen, Y., Thompson, W., Semenciw, R. and Mao, Y. (1999) Epidemiology of Contralateral Breast Cancer. Cancer Epidemiology, Biomarkers and Prevention, 8, 855-861.

[45] Pakseresht, S., Ingle, G.K., Bahadur, A.K., Ramteke, V.K., Singh, M.M., Garg, S., and Agarwal, P.N. (2009) Risk Factors with Breast Cancer among Women in Delhi. Indian Journal of Cancer, 46, 132-138. 
[46] Afonso, N. (2009) Women at High Risk for Breast Cancer-What the Primary Care Provider Needs to Know. The Journal of the American Board of Family Medicine, 22, 43-50. https://doi.org/10.3122/jabfm.2009.01.070188

[47] American Institute for Cancer Research (2007) Guidelines for Cancer-Prevention: Healthy Living for Cancer Prevention. http://www.aicr.org

[48] Ogundiran, T.O., Huo, D., Adenipekun, A., Cambell, O., Oyesegun, R., Akang, E., Adebamowo, C. and Olapede, O.I. (2010) Case Control Study of Breast Size ND Breast Cancer Risk in Nigerian Women. American Journal of Epidemiology, 172, 682-690. https://doi.org/10.1093/aje/kwq180

[49] Berstad, P., Coates, R.J., Bernstein, L., Suzanne, G., Folger, S.G., Malone, K.E., Marchbanks, P.A., Weiss, L.K., Liff, J.M., McDonald, J.A., Strom, B.L., Simon, M.S., Deapen, D., Press, M.F., Burkman, R.T., Spirtas, R. and Ursin, G. (2010) A Case-Control Study of Body Mass Index and Breast Cancer Risk in White and African-American Women. Cancer Epidemiology, Biomarkers and Prevention, 19, 1532-1544. https://doi.org/10.1158/1055-9965.EPI-10-0025

[50] Wrensch, M., Chew, T., Farren, G., Barlow, J., Belli, F., Clarke, C., Erdmann, C.A., Lee, M., Moghadassi, M., Perkin-Mentzer, R., Quesenberry, C.P., Saunders-Mason, V., Spence, L., Suzuki, M. and Gould, M. (2003) Risk Factors for Breast Cancer in a Population with High Incidence Rates. Breast Cancer Research, 5, 88-102. https://doi.org/10.1186/bcr605

[51] Hussain, S.K., Altieri, A., Sundquist, J. and Hemminki, K. (2008) Influence of Education Level on Breast Cancer Risk and Survival in Swedish between 1990 and 2004. International Journal of Cancer, 122, 165-169. https://doi.org/10.1002/ijc.23007

[52] Gibson, L.J., Héry, C., Mitton, N., Gines-Bautista, A., Parkin, D.M., Ngelangel, C., and Pisani, P. (2010) Risk Factors for Breast Cancer among Filipino Women in Manila. International Journal of Cancer, 126, 515-521.

https://doi.org/10.1002/ijc.24769

[53] Celik, S. and Aksoy, G. (2007) Identification of Risk Factors for Breast Cancer for Women in Istanbul. The Open Nursing Journal, 1, 6-12. https://doi.org/10.2174/1874434600701010006

[54] Saweer, A.A.L., Yacoub, F. and Mohammed, N. (2003) The Prevalence of Risk Factors among Women Diagnosed with Breast Cancer. Bahrain Medical Bulletin, 25, 1-7.

[55] Ayoade, B.A., Tade, A.O. and Salami, B.A. (2012) Clinical Features and Pattern of Presentation of Breast Diseases in Surgical Outpatient Clinic of a Suburban Tertiary Hospital in South-West Nigeria. Nigerian Journal of Surgery, 18, 13-16. 